\title{
The Place of Women in Higher Education: A Philosophical-Historical Perspective
}

\author{
Dr. Rachel Ndinelao Shanyanana \\ University of Johannesburg, South Africa \\ Emails: rachelsh@uj.ac.za or rdninelaokaleb@gmail.com \\ Dr. Amasa Philip Ndofirepi \\ University of Johannesburg, South Africa \\ Emails: amandochi@gmail.com or ndofiamasa@live.com
}

Doi:10.5901/mjss.2014.v5n23p2168

\begin{abstract}
The assumption that higher education institutions on the African continent, after gaining political independence from the erstwhile colonisers, would be accessible to all people, irrespective of gender, race, status, ethnicity or religion has not had meaningful practical consequences. In higher education, especially universities, there has not been convincingly adequate space created for women and hence their involvement remains at the periphery of its practices. In this theoretical paper, we argue that although women are involved in the current higher education, their participation is still placed at the margin of the educational practices just like in the pre-colonial and colonial periods. We posit that while the time and space have changed, the nature of involvement throughout the pre-colonial, colonial and post-colonial epochs, women have been and are still left at the periphery of higher education on the African continent. It is our case that if authentic liberation for all is to be realised, the involvement of all people, including women as equal agents in higher education, ought to be the epicentre of all higher education goals and practices. This philosophical paper therefore interrogates and presents a historical exposé of Higher Education (HE) in Africa, from pre-colonial, colonial through to the post-colonial epochs, in relation to how they place women within university institutional and educational practices.
\end{abstract}

Keywords: higher education, liberation, women, pre-colonial, colonial, post-colonial, Africa

\section{Introduction}

African countries have experienced a long period of colonialism imposed by most prominent Western colonial powers such as France, Belgium, Britain, Germany and Portugal, to mention just a few. Upon liberation, the assumption was that higher education institutions in these countries would be accessible to all people, irrespective of gender, race, status, ethnicity or religion, resulting in knowledge production relevant to the context and local interest. The idea of liberation in Africa was influenced extensively by the Brazilian philosopher, Freire's (2004) "liberatory" perspectives on education, which entailed setting one free from all forms of domination and dependence. However, even though African educational institutions claim to have created a space for women in higher education, especially universities, their involvement remains at the margins of the educational practices just like in the pre-colonial and colonial periods. We argue for the involvement and recognition of all people as equal agents are at the epicentre of higher education (HE) in Africa including women. We offer an account of the place of women in African higher education (AHE), tracing it from the precolonial, and colonial through to the postcolonial periods that shaped the contemporary higher education.

Although this paper discusses HE in Africa (as tertiary education), Lulat (2005, p. 25) contends that history reflects that, in the absence of all other forms of HE in a society, HE may mean any post-primary level of education (such as at secondary level and teacher training). In other words, HE is an educational system that constitutes universities and any other degree-granting colleges. Expounding the notion of HE Abdalla (cited in Assié-Lumumba, 2006a, p. 19) posits that:

A university is but one of the institutions of higher education. It brings men and women to a high level of intellectual development in the arts and sciences, and in the traditional professional disciplines, and also promotes high level research. On the one hand, therefore, it is a community of persons engaged in study and research. On the other, it is a source of highly trained manpower (sic) for the professions. But it is not alone in this second role. There are other institutions of higher education which offer post-secondary education and training courses and programmes of instruction in technical and vocational subjects and practical fields of work, all geared to producing middle grade technicians. 
The above citation underscores the fact that institutions of higher learning can be categorised broadly on the basis of their mission and goal, their primary functions with regard to teaching and learning, research and service, the requisite qualifications of the faculties, the criteria for admission of students, the duration of the programmes they offer, and the types of degrees they confer (Assié-Lumumba, 2006a, p. 19). It can be said that the terms "higher education" and "tertiary education", which embody all forms of organised educational learning and training activities beyond the secondary level, are often used interchangeably. These terms therefore may refer to either universities, polytechnics, training colleges or all forms of professional institutions. Furthermore, universities are the largest repositories of certified knowledge and accommodate the concentration of those certified as experts, and who possess the specialised skills and knowledge that societies need for their advancement and development (Okolie, 2003, pp. 238-239). Clearly, university is expected to play a central role in the national project of social progress. Notwithstanding, Assié-Lumumba posits that "higher education is not the sole space but it is, without doubt, central to the acquisition and production of knowledge that shapes the contemporary world" (2006a, p. 9). With this understanding, a philosophical analysis of the historical account of HE in Africa ranging from the pre-colonial, colonial to the post-colonial epochs is indispensable, particularly the common theme of placing women at the margin of educational practices.

The critical question that gave impetus to this journey is: What dominant ideas underlie HE in Africa in different periods and what was/is the place of women throughout history? This question is enthused by the notion that history helps to yield an understanding of how past events shape present systems and in the context of this debate the current HE system in Africa. On this view, Hogan and Smith (2003, p. 166) argue that public HE is not an autonomous practice, but rather a component of the whole system within a given society or government, either autocratic or democratic. This implies that, since HE is not an independent entity, it cannot be examined without touching on the politics embedded in its practices. As a consequence, this paper traces the historical moments of $\mathrm{HE}$ on the African continent with the intention of demonstrating how women were/are involved in different eras.

To accomplish the above, pre-colonial HE is pronounced, with particular interest in the ancient African indigenous higher learning and Egyptian education systems. This is done in reaction to widespread contemporary claim that postcolonial type of HE was pioneered by the Western colonial states (see Assié-Lumumba, 2006a; Divala, 2008; Lulat, 2005). In Africa and the world over, Egypt piloted HE in the written form, which makes her one of the world's early great civilisations. Evidently, the first examples of formal HE institutions in Africa can be traced to Ancient Egypt, where high arts, religious education, medical education and many other forms of education were enacted. This nurtured young generation as early as C. 2000 BC specifically in the construction of pyramids (Lulat, 2005, p. 44; Asante, 2011). Secondly, the involvement of women in colonial higher education is interrogated based on the different influences on the continent, namely Arab-Islamic, Anglophone, Francophone and other Western colonial powers. This succinct exploration is pertinent in order to gain a better and deeper understanding of existing involvement of women in HE on the continent. Thirdly, the post-colonial higher education and involvement of women is analysed in terms of the shift from colonial supremacy to democracy in relation to the involvement of women including the effects of globalisation to such practices. More specifically, this analysis establishes to whether HE has a chance of bleaching the bridge on the dilemma of women's involvement in the contemporary epoch. This article calls for the repositioning of women from the margin to the center and further interrogation for subtle mechanisms underlying AHE practices which impede women's contribution.

The paper firstly offers an analysis of pre-colonial education and the involvement of women in Africa. Secondly, it presents the underlying rationale of colonial higher education and how women were involved. Thirdly, explores how women are represented in the contemporary higher education in postcolonial Africa. This exploration also makes a brief highlight on the effects of globalisation to women involvement, which has exacerbated the placement to the margin. Fourthly, it engages on the dilemma of women's involvement as exemplified by their representation as students and staff members as well as researchers. Lastly, it makes a call for the repositioning of women from the margin to the centre of Africa's higher educational practices in the $21^{\text {st }}$ century.

\section{Pre-Colonial Higher Education and Women in Africa}

Various studies prove that HE was not a new practice in African society before the Western colonial influx. In their separate research, Ajayi, Lameck, Goma and Ampah (1996) and Lulat (2005) trace the inception of HE back to the ancient centres of civilisation on the African continent, such as Egyptian knowledge and the entire African indigenous ways of knowledge production at large. All studies recognise that $\mathrm{HE}$ in Africa was not initiated by European influences, but had been there before the colonial period. Although the existence of indigenous $\mathrm{HE}$ in Africa has been criticised and refuted by a number of scholars (see Ajayi et al., 1996; Assié-Lumumba, 2006a), many African researchers have defended its uniqueness and survival prior to colonial occupation. For instance Brown and Hiskett (1975, pp. 19; 22) 
argue that $\mathrm{HE}$ in ancient Africa was characterised by initiation into the life of the adult community. This form of education was non-formal in nature, and children and young people were expected to imitate and emulate adult achievements through the inculcation of traditional wisdom in the form of folklore and modes of learning. One can construe that HE in Africa existed before colonial era.

To answer the question on the existence of ancient indigenous higher education system and the forms of knowledge, Ajayi et al. (1996, p. 5) contend that:

Indigenous higher education produced and transmitted new knowledge necessary for understanding the world, the nature of man, society, God and various divinities, the promotion of agriculture and health, literature and philosophy.

This picture of HE in Africa depicted above was initially drawn from elements of African knowledge. Such relevant forms of knowledge were shared orally and highly embraced by all members of the society. Outstandingly, Divala (2008) posits that, despite the claim that African societies lacked technological advancement, their form of education meant that their forms of knowledge superseded what an ordinary person needed to know in order to survive as a member of a particular society. Evidently, using Odera Oruka's findings, Ajayi et al. (1996, pp. 3-5) argue for the existence of philosophers or original thinkers in African indigenous cultures who created and nurtured forms of informal HE. In his view, the system of HE at that period remained "predominantly oral, eclectic and even esoteric" (1996, p. 4). Specific individuals - mostly men - were rewarded with gifts and even pieces of land for certain forms of higher knowledge that were recognised and promoted by the society. It is therefore compelling to note that the distinctiveness of African forms of $\mathrm{HE}$ in which philosophic knowledge existed, regardless of the fact that there were operated outside the confines of the communal pool of knowledge, were highly treasured by the community and considered as part of the community (Divala, 2008, p. 37). Simply put, apart from the given oral forms of indigenous HE in some parts of Africa, as emphasised above, there was a written form that originated in Egypt.

Lulat $(2005$, p. 3) argues that, long before the arrival of Western colonisation, some parts of Africa possessed institutions of higher learning, thus could boast of a tradition of HE in which the pursuit of knowledge was a worthy endeavour that any society would want to encourage. Undoubtedly, Egypt completed the pyramids long before European HE had been initiated. As a result, the Bibliotheka Alexandrina is one of the early institutions of HE in the world and its library became known as the greatest cultural repository of its time. It attracted all the leading scholars (men) from the Egyptian, North African, Greek, Roman and Jewish worlds (Ajayi et al., 1996, p. 6). The nature of the HE offered was intended to satisfy the quest for knowledge, while taking into account the fulfilment of responsibilities relevant to the community and within a particular culture (Ajayi et al., 1966, p. 5). It is on these grounds that one can conclude that HE in Egypt strived to nurture knowledge in the people for the good of the community, while addressing daily issues. Riad, cited in Ajayi et al. (1996, p. 6), points out that:

\section{Scientists and men of letters lived in the [HE] institution. They were housed and fed and were able to give themselves up entirely to their research and students, with no menial duties to perform. Its organisation was similar to that of modern universities, except that the resident scholars were not required to give lectures.}

In view of the above analysis, African indigenous $\mathrm{HE}$ is diverse, not only in terms of the acquisition of indigenous knowledge, but also in the degree of civilisation. As a result, African written form of HE serve as forerunners of world civilisation, of which such an advanced knowledge was meant only for men. This education is justified as being of current significance and safeguarded by numerous African scholars, even in the 21st century (see Teferra \& Altbach, 2004; Assié-Lumumba, 2006a). Wallbank (1964, p. 16) underlines that the unique and admirable features of various elements in African indigenous culture, particularly those of art and music, were meant for boys and men, rather than for girls and women. The foregoing affirms that African indigenous HE in the pre-colonial period emphasised high skills and knowledge to be imparted into boys and men for the well-being of the community. Unfortunately, this prestigious education system favoured males over females and thus perpetuated imbalances in terms of their roles in such $\mathrm{HE}$ practices.

Women were assigned to substandard duties and unrecognised skills attributed to child bearing and rearing babies, looking after children, and caring for men and the elderly. This is one of the issues not interrogated in the marginalisation and keeping of women at the periphery of $\mathrm{HE}$ during that period. The women's place in contemporary times from AHE can be traced to pre-colonial times, since from then it is symbolic that women were not regarded as equal members of society in comparison to men, which clearly indicates how the pre-colonial period initiated a maledominated society. For a more comprehensive insight into the way women were involved in HE considering time and space perspective, we proceed to discuss in the next section women's involvement in colonial period. 


\section{Women in Colonial Higher Education}

Africa has a long history of colonisation. The first wave was called ancient colonisation and began in Northern Africa from Europe and Western Asia as early as 570 to 526 BC, led particularly by the Greeks and Phoenicians (Lulat, 2005, p. 81). Since Islam started to spread in Africa in the middle of the 7th century, this is the period when Africa fell into the hands of Arabs, who brought the Islamic religion and Arabic language. Then came the early modern period, when the European states engaged in the exploration of Africa, especially sub-Saharan Africa, in order to increase Western knowledge, to spread Christianity and to increase national esteem on the basis of colonisation. This period was followed by the famous phase referred to as the "Scramble for Africa" in the late 19th and early 20th centuries. One can infer that colonisation commenced in the period before the birth of Christ in different regions of the continent. In Wallbank's (1964) analysis, colonisation of Africa stirred by a rapid change, tension and unrest that took place in the world in 1950s. These events led to a major political development in the Western world to invade the so-called "unchanging Dark continent" Africa (Wallbank, 1964, p. 11). The rationale embedded within the European education in Africa and their objective to establish or not to $\mathrm{HE}$ on the continent is questionable. Logically, the purpose was to fulfil the colonisers' vision mainly to exploit the raw materials found on the continent for their benefit, while educating African men as their means of achieving their goal.

It can be argued that the colonial states were more captivated by the richness of African natural resources, which were still raw and unexploited, than by the people and their development. In relation to HE, Ekong (in Rottenburg, 1986, p. 37) states that Western colonial powers had no interest in HE in their African dependencies. In spite of the above, some local colonial administrators initiated vocational training institutions to produce assistants to support the colonial ideologies in different countries in Africa. In essence, the colonial HE was highly structured to prepare people to serve as government machinery that maintained and promoted a colonial ideology in different regions and countries on the African continent. But according to Magubushka, Schomburg and Teichler, HE was neglected during the colonial era and was designed to fulfil the needs of the colonial powers, and thus was not suitable to serve the national development of the newly independent states (2007, p. 1). From the preceding discussion, we infer that religious and colonial education was basic and favoured men, rather than empowering all people, including girls and women. This colonial HE process had not only starved the African masses of education, but also sustained male domination, which has exacerbate the subjugation of women on the continent to this date. By interrogating the history, we recognise how African countries vary significantly from one another in ideology and features that influenced HE institutions and the place of women in higher education. At different periods, we conclude that HE was used as a tool to discourage African natives from what is called 'backward beliefs and practices', and to assimilate them into Western colonial beliefs and trends of male domination. Clearly, colonial education used mostly men to maintain colonial ideologies (see Assié-Lumumba, 2006a). Also, despite the fact that colonial basic education was encouraged for the local people, specifically for males, HE was promoted only slightly but solely for the few, was highly elitist and irrelevant to the broader contexts of Africa.

\section{Women in Higher Education in Postcolonial Africa}

The concept "post-colonial" can be expounded in two ways: firstly, as a state that came after the colonial state; and secondly, as an ideology that a state uses to surpass or supplant colonial rule (Spencer, 2012). In this context, we will engage with both perspectives, which underline the intention of liberation and independence on the African continent. At the time of independence, education, particularly $\mathrm{HE}$, was expected to play a central role in the national project of social progress. However, "higher education is not the sole space but it is, without doubt, central to the acquisition and production of knowledge that shapes the contemporary world" (Assié-Lumumba, 2006a, p. 9). In the period after independence, from the 1960s through the 1970s was regarded as a liberal and transformative period for the postcolonial society in Africa (Khelfaoui, 2009, p. 23). The first wave of creating African HE specifically the university took place during the 1960s, which was declared by the United Nations as the "Development Decade". Moreover, most independent African countries required concerted efforts to initiate substantial reforms. The theory of human capital was prominent in industrialised nation-states such as the United States of America (USA), where education was expected to be a powerful instrument for redressing the structural inequalities embedded in society especially creating a space for women (Assié-Lumumba, 2006b, p. 9). As a result, human capital theory became dominant in developing regions such as Africa. In spite of the continent's struggle for political liberation, this principle of human capital was infused into the nationalist discourse and liberation agenda.

The intention underpinning the principle of human capital is the creation of a linear and positive relationship between education and development, both at the individual and societal level, that is, the higher a person's level of HE, 
the higher their productivity. For that reason, some African leaders such as Ghana's Kwame Nkrumah, Senegal's Leopold Senghor and Tanzania's Julius Nyerere thought it was imperative to transform education. Sawyerr (2002, p. 2) articulates the African idea of transformation as follows:

\begin{abstract}
Widespread university is essentially a postcolonial phenomenon ... and only 18 out of 48 countries of sub-Saharan Africa had universities or colleges before 1960. With the approach of political independence or immediately thereafter, many African countries regarded the establishment of local universities as a major part of the postcolonial national development projects. The new universities were to help the new nations build up their capacity to manage and develop their resources, alleviate the poverty of the majority of their people, and close the gap between them and the developed world.
\end{abstract}

This is illustrative of the way in which nationalist leaders in Africa viewed and envisioned the transformation of HE on the continent. An example of a transformative agenda in African states incorporates the goals of post-colonial $\mathrm{HE}$. The Accra conference of the Association of African Universities (AAU), held in Ghana in 1972 under the theme 'Creating African Universities', deliberated on the rising and increasing issues confronting African universities. At that conference, according to Rottenburg (1986, pp. 52-54), participants agreed that, it was essential for universities to free themselves from intellectual domination and begin to derive incentives from their African environment and seek continuity with African tradition despite their origination in foreign Western HE institutions;. Most importantly, AAU tasked universities with "a commitment to active participation in social transformation, economic modernisation and the training and upgrading of the total human resources of the nation and not just small elite" (in Rottenburg, 1986, pp. 52-54).In addition, the AAU's commitment appears to be a response to an urgent need to include women's involvement in AHE towards transformation. Therefore, AHE particularly the university would have to adhere to fundamental commitment and role, of which the pursuit and dissemination of knowledge have to be locally motivated and orientated. Such fundamental role, as prescribed by the AAU, demonstrates the African people's vision to break away from the colonial (as well as the precolonial) legacy, and to include girls and women in HE. Such roles have placed the university in a position as a conduit of transformation to educate manpower - specifically women. Interestingly, the AAU's call for a transformative agenda towards the production of locally motivated knowledge invites the question: what is the place of women in African higher education?

We contend that the continent's transformative commitment could not be realistic without an indication of the mechanism for the acceleration of women's access to AHE. Providing a glaring image of women enrolment to HE in Africa, the United Nations Educational, Scientific, and Cultural Organization Institute for Statistics (UNESCO-UIS (2009) showed that, globally, the enrolment ratios of women and men reached parity between 1970 and 2007. However, in Africa - taking Ethiopia and Mozambique as examples - a third or fewer tertiary graduates are female, in comparison with North America, Europe, Latin America, the Caribbean and Central Asia, where female enrolment rates are higher than in Africa (UNESCO-UIS, 2009). The given statistics indicate that, internationally, the call for women's involvement (access) to HE had been made in the early 1970s, yet this appeal has not been given the priority it deserves in Africa. Although ideas on women's full involvement have drawn some attention in HE during the post-colonial epoch, women's marginalisation has been firmly identified throughout the African continent as constituting the most rampant expression of injustice in terms of access to and achievement based on educational opportunity (see Assié-Lumumba, 2006a, p. 9).

Even though AHE institutions have been influenced by ancient indigenous ways of life during pre-colonial era, it is also mirrored after those of the former colonial powers. Nonetheless, we argue that the contemporary African societal realities, needs, constraints and assets demand innovations that respond to local needs in search of transformation particularly the involvement of women. Primarily, the postcolonial nationalist struggled for independence with the primary idea of creating an accessible $\mathrm{HE}$, with the aim of producing skilled manpower to run a modern government and economy, as well as for other areas of governance. The underlying assumption was that HE ought to be opened to all people in Africa, especially women who have been placed at the margin throughout history. Taking into account the evolution of globalisation and the concomitant notion of neoliberalism, we proceed to probe on the effects of the former on AHE. However, due to the nuanced perception of globalisation in post-colonial Africa, time and space will not allow for a detailed account of its effects to women's involvement in HE.

\title{
4.1 Globalisation and its effects to women involvement
}

According to Peters and Roberts, the concepts neoliberalism and globalisation cannot be used interchangeably. They argue that neoliberalism as an ideology, is a "framework within which ideas about social, institutional and cultural life are expected to operate" (Peters \& Roberts, 2008, p. 1). That entails the implementation of policies namely corporatisation, marketisation, and privatisation across the globe. As a multifaceted process of neoliberal economic policies, globalisation 
engenders creativity of economic interaction that embraces international communities. As a neoliberal project, globalisation calls for the economic model of $\mathrm{HE}$ and was strongly imposed on higher educational policies across the developing countries by the World Bank's Structural Adjustment Programs (SAPs) in the 1980s (Ajayi et al., 1996). This project created the assumption that exported industrial production inevitably would create possibilities for women's involvement in AHE, yet there were inherent predicaments.In that regard, globalisation in Africa has been "articulated primarily through SAPs and that globalization throughout its projects has accelerated the corporation of unitary management, commercialization of learning and commoditization of knowledge" (Zeleza, 2004, p. 42). Nonetheless, knowledge has been increasingly commodified as it is packaged into smaller marketable units in an industrialised curriculum (Leathwood \& Read, 2009, p. 2). In other words, globalisation has turned HE institutions into an economic investment rather than a common good that would afford everyone (especially marginalised groups - in these instances, women and the poor) access to institutions of HE and to be fully included. One may possibly conclude that HE in Africa is not only considered as a manufacturer of technicians, but also as a space for the elites and privileged, rather than for all eligible citizens (including women).

Due to each nation's individual history, traditions, cultures, resources and priorities, globalisation has ultimately impacted negatively on the educational development at universities in in developing countries (Knight, 2008, pp. 5-6). Nevertheless, we question the extent to which African postcolonial HE may succeed in creating a space for women considering the perpetual male dominated pre-colonial and colonial legacy as well as the current effects of globalisation. Despite several conferences calling for equal representation of women and their contribution to knowledge production and scholarship and as students in AHE, women are still shunned in such practices, which lead to their underrepresentation at all levels as will be discussed below.

\section{The Dilemma of Women's Involvement in Higher Education}

We have noted the origins of HE in Africa prior to colonisation characterised by skills and knowledge which favoured men resulting in the emergence of male-dominated institutions. Ajayi et al. (1996) point out that men were seen as valuable agents to bring about national development and therefore were held responsible for the well-being of women and children hence women were allocated low-level skills, while the opposite was true for men. With the legacy of the male-dominated spaces, HE institutions worsened women's access to such institutions and their under-representation in knowledge production. This ideology of producing technocrats with technical know-how does not have the ethos of caring for others, in Waghid's (2012) terms, since there is a greater concern about what is produced (the end product), than with who produces and how the perceived prominent knowledge is produced. Hence, women's placement at the margins in $\mathrm{HE}$ practices with respect to access to knowledge production.

\subsection{Women representation as students and staff members}

Here, we argue that throughout history (both pre-colonial and colonial period) AHE favoured men, the post-colonial system has also failed to create an inclusive and equal environment for women. Assié-Lumumba (2006a, p. 18) says that, since most of Africa's political leaders, bureaucrats and scholars are products of colonial education; this resulted in AHE institutions applying the same mechanism of excluding women from knowledge research and leadership positions. One can say that AHE has largely passed colonial strategies and practices into the postcolonial education systems - a situation that deprives women of making valuable contributions to higher education. Teferra and Altbach assert that while the state and trend of HE institutions in Northern Africa are considerably different from those in sub-Saharan Africa, which spurred diversity in terms of function and quality, there are common aspects such as financial resources, demand for access, the legacy of colonialism, and longstanding economic and social crises in many countries that affect their efficient functioning (2004, pp. 22-23). UNESCO (1998, p. 2) observes that although there were no formal obstacles preventing women from reaching high positions in colleges and universities at the time, men still dominated at all levels of society. The above concern raises a question about why women are unable to obtain equal access, despite the fact that there are no explicit hindrances to such roles.

Contemporary efforts and initiatives to transform universities, especially creating space for women, met with different challenges especially the SAPs' and globalisation project which positioned learning into a mere technical and professional fields at the expense of humanities and basic sciences. We argue that globalisation has radically distorted the ideals of HE in Africa in terms of teaching, research, development and knowledge production, particularly with its attendant call for the commoditisation and marketisation of knowledge. This has impacted negatively on women's access to $\mathrm{HE}$ institutions, to employment as well as to making a contribution to knowledge production and dissemination. In 
addition, this negation allows universities to generate new organisational forms, practices and knowledge production, with an emphasis on entrepreneurial skills, characterised by increasing market-like behaviour and governance, which are already dominated by men (Subotzky, 1999, p. 221). Clearly, this perspective allocates universities a market orientation where knowledge has to be bought as a product (Knight, 2008, p. 13). Education, in this sense, is perceived as a private good for individual consumption and benefit, and only those who possess the capital and are well prepared to access such markets and a comparatively advantaged to get the best products. Most male students tend to follow IT and science subjects due to high funding allocations in those fields, while fewer (female) students register for Humanities and Social Science subjects. In this way, women are unable to get involved into HE due to their economic and social status and capacities.

Poignantly, statistics illustrate that there has been an increase in the raw numbers of female students in $\mathrm{HE}$. Nonetheless, high attrition rates in the lower levels of the education system comprises a persistent dilemma, as this leads to low enrolment at the HE level (Meena, 2007). Regarding the representation of women as students, Yizengaw (2008, pp. 10-13) points out that the problems are mismanagement and divergence in adopting the World Bank policy as reflected by the gross enrolment ratio of female students remained at around 2\% between 1995 and 2004, compared to $5 \%$ and above for male students. In 2004, of the 3.4 million total student enrolment in tertiary education, the proportion of female students was only $38 \%$, while the enrolment of female students in mathematics, science and engineering was particularly low. UNESCO-UIS (2009, pp. 15-16) illustrates the disparity in growth between men and women in subSaharan Africa. Some statistics on the disproportion among students who have access to HE shows that approximately $6.8 \%$ are male while $4.5 \%$ are female. These statistics mean that, for every 100 male students enrolled in 2007, there were only 66 female students. The preceding statistics reveal that women are at the margin of HE in Africa in comparison to their men counterparts, which incite inequality. We maintain that universities in Africa are integral sites by virtue of their emphasis on the production of knowledge and research; however, they also perpetuate gender biases, which to a large extent is problematic. Kyomuhendo (2001, p. 10) calls for a re-examination of the systems, structures, norms and values of society that govern and define the universities and their ways of operation, which are distinctly patriarchal in nature.

\subsection{Women representation as researchers}

The low representation of women as staff members and academics can be linked to the under-representation of female students in AHE. This situation is attested to by the number of women who are researchers and academics, as well as the number of publications on the continent. The concern is that women research and disciplines that are considered as lower in value that will not necessarily secure them good work prospects in society. Yizengaw (2008, pp. 10-13) shows that the number of female teaching staff was just $4 \%$ in 2004, which had a negative impact on the number of women researchers in AHE. A UNESCO-UIS report (2009) claims that women are under-represented and under-measured in science in AHE. Concurrently, the report states that, women made up approximately $25 \%$ of the world's researchers. The point is that under-representation of women in research activities can be traced back to education systems, particularly at the HE level. It is proposed that other aspects, such as stereotyping, work-life balance, labour market conditions, governance and the role of researchers in society may also hinder women's access to continuity and advancement in research positions. It is questionable whether AHE institutions ought to equip women with research capability and expertise to contribute to a democratic society. We agree with UNESCO-UIS (2009) that women are still faced with considerable barriers when pursuing $\mathrm{HE}$ on the continent. As a result, men remain dominant in accessing $\mathrm{HE}$ as students and researchers, retaining leadership positions and determining the form of knowledge to be offered (see AssiéLumumba, 2006b; Meena, 2007). With the pre-colonial and colonial legacy of placing women at the edge of HE practices, it is unsurprising to observe how the current $\mathrm{HE}$ continues to maintain the similar treatment. Alongside the encumbered effect of globalisation, Cloete (2002) points out that many emerging global knowledge partnerships and research networks continue to be dominated and controlled by men in areas that are historically gender biased, such as research and consulting.

Using the South African case, Cloete (2002) argues that research remains in the hands of males, as was evident from the research, which found that men produced $83 \%$ of the scientific output between 1990 and 1998. This simply implies that women are less likely to engage in research, and henceforth men continue to dominate knowledge production. By so doing, knowledge production has been and continues to be produced to the advantage of its producers, who are men, and relegates issues related to women to the periphery of HE. Women continue to depend on men to produce knowledge for their benefit, rather than contributing to it themselves. Clearly, although AHE has risen to occupy an integral part of modern societies with the largest repository of certified knowledge focusing on the production of those certified as experts who possess the specialised skills and knowledge that societies need for their advancement and 
development, such experts were mostly men (Okolie, 2003, pp. 238-239). One can argue that the focus on men to acquire such skills and knowledge, as it was in the pre-colonial and colonial system, continue to promote a maledominated HE on the continent. This exhibits how HE continues to exclude women as students and staff members, which invariably results in inequality on the continent. This invites us to briefly make a case for a renewed positioning of women in the academy in Africa.

\section{Repositioning Women in Higher Education in $21^{\text {st }}$ Century Africa}

In this section, we argue that women's involvement and representation has been and still limited since history despite the post-colonial initiatives of making HE accessible to all people regardless of gender, race, class, and ethnicity etc. In order to justify our argument and comprehend the place of women and their involvement in HE, we draw from Morrow's interpretation of access. Morrow (2007, pp. 35-39) identified two types access, (i) formal access and (ii) epistemological access. Formal access deals with admission to institutions of $\mathrm{HE}$ in terms of the number of students, whereas epistemological access entails how many institutions provide access to the goods it distributes to those it formally admits, that is, the knowledge shared system. In his view, formal access takes place when more women (as students or staff members) are given special entry to $\mathrm{HE}$, but epistemological access is enabled when women who gained formal access to $\mathrm{HE}$ are offered spaces to share their knowledge by means of research outputs at conferences and in publications, and to make contributions to policy changes. Formal access can be exemplified by the number of women at HE institutions, while epistemological access manifests when those who are formally granted access to HE are afforded opportunities to contribute to decision making and share their knowledge in policy formation.

Morrow (2007, p. 39) has rightly noted that, if we promise our students (in this case women) spaces in HE by offering them formal access, but break our promise by not offering them adequate epistemological access, we not only betray their personal aspirations, but also undermine some of the central ideals of HE. The point is that despite fact that women have attained formal access, which is involving them in HE practices, their position remains on the margin. Hence, the lack epistemological access, which could facilitate women's repositioning from the margin to centre of HE practices; namely contribution to knowledge production, research and decision making. In view of the above interpretation, it is clear that women as students and staff members are dismally involved as depicted statistically. Undeniably, a substantive number of women are involved in the current HE, yet they are still placed at the margin of the educational practices just like the pre-colonial and colonial periods.

Prominently, African states through their Ministries of Education, have taken on the task of pursuing a number of strategic objectives, including improved access, participation and equity with an emphasis on marginalised groups in this case women, such initiatives have not really changed their place, which is the margin of higher educational practices. We concur with the Commonwealth Secretariat's $(1999$, p. 10) position that a more truly gender-responsive culture requires gender equity in access, the redressing of structural barriers that influence the access and participation of both sexes, and women's active role in decision making in the management and administration of HE. In essence, our argument is that although globalisation lives itself out in different ways and permeates HE on the continent, the place of women in such practices can be traced back from the pre-colonial and colonial epochs. Undeniably, one cannot ignore various dissatisfactions of the effects of globalisation on AHE, especially its radical call for a market model, as is evident in the work of African scholars engaged throughout the paper. However, the dilemma of placing women and other marginalized groups at the margin of the post-colonial HE practices cannot be merely blamed on the commodity approach. The point is, if AHE is serious about repositioning women from the margin to the centre of its practices, they will create enabling environment where women can make meaningful contributions to decision-making, policy formation and knowledge production.

\subsection{What is the way forward for HE in Africa?}

Our preposition is that HE needs to re-evaluate the historical legacy of women involvement especially the constant positioning at the margin of its practices and the underlying rationale of transforming the institutions. The call is for critical interrogation of the historical legacy and constant deliberations to why women's placement at the margin continues. We argue that, if HE in Africa are to locate a place in the $21^{\text {st }}$ century, there is an urgent need for repositioning of women which begins by rethinking new mechanisms of creating conducive environment where all people can play the central role(not marginal) and as equal participants in all circles of higher educational practices. We cement Waghid (2012, p. 72) position that university education is distinct from take its role of equipping people (both men and women) with technical know-how and with democratic virtues such as critical thinking, respect and caring, to mention a few, which seem lacking 
in our postcolonial university system. Taking into account the figures provided above, one can conclude that women's exclusion in AHE is connected to their consistent under-representation in AHE teaching, research and academic administrative positions. Therefore, there is a need to interrogate the structures and encompassing values that the $\mathrm{HE}$ system itself reproduces especially the highly talked about globalisation. This verifies to why unequal accessibility to HE has been and still a concern on the continent. As a result, we argue that the repositioning of all people as equal agents in all educational activities should be central in AHE in order to play their relevant role in the $21^{\text {st }}$ century.

\section{Conclusion}

In the paper, we have argued that HE has been in Africa before colonisation, both in an oral and a written form. We also have shown that AHE during different epochs ranging from pre-colonial, colonial and post-colonial has placed women at the margin of its practices. Our argument is that, although post-colonial African educational institutions' underlying assumption was that HE ought to be opened to all people in Africa, especially women who have been placed at the margin throughout history, their involvement remains at the periphery just like the previous periods. We have indisputably agreed that women are involved in the current $\mathrm{HE}$, yet their position in knowledge production and dissemination is still on the margins of higher education practices. We have argued that although the time and space has changed, the nature of women's involvement throughout history remains on the periphery of educational practices. We exposed why women continue to be at the edge of HE practices especially knowledge production, access to which could empower them for social growth. We conclude that critical interrogation is required towards the realization of the continent's transformative agenda especially the competing demands of globalized knowledge production. We make a clarion call for studies of contemporary institutions to critically reflect on the complexity of the inclusivity of women in higher education in order to realise genuine transformation of the academy in higher education.

\section{References}

Ajayi, J. E. A., Lameck, K. H., Goma, G., \& Ampah, J. (1996). The African experience with higher education. Accra: Association of African Universities.

Assié-Lumumba, N. (2006a). Higher education in Africa: Crises, reforms, and transformation. Dakar: Council for the Development of Social Science Research in Africa.

Assié-Lumumba, N. (2006b). Empowerment of women in higher education in Africa: The role and mission of research. A paper commissioned by the UNESCO Forum on Higher Education, Research and Knowledge, No. 11, ED.06/Africa/2.

Brown, G. N., \& Hiskett, M. (Eds.). (1975). Conflict and harmony in education in tropical Africa. London: George Allen \& Unwin Ltd.

Cloete, N. (2002). Transformation in higher education: Global pressures and local realities in South Africa. Cape Town: Juta.

Commonwealth Secretariat. (1999). Gender mainstreaming in education: A reference manual for governments and other stakeholders. London: Commonwealth Secretariat.

Divala, J. J. K. (2008). Is liberal conception of university autonomy relevant to higher education in Africa? Unpublished doctoral dissertation. Stellenbosch: Stellenbosch University.

Freire, P. (2004). Pedagogy of hope. Reliving pedagogy of the oppressed. New York: Continuum.

Hogan, P., \& Smith, R. (2003). The activity of philosophy and the practice of education. In: N. Blake, P. Smeyers, R. Smith, \& P. Standish. (Eds.), The Blackwell guide to the philosophy of education (pp. 165-180). Oxford: Blackwell.

Khelfaoui, H. (2009). The Bologna process in Africa: Globalisation or return to "colonial situation"? JHEA/RESA, 7(1\&2), 21-38.

Knight, J. (2008). Higher education in turmoil: The changing world of internationalization. Rotterdam \& Taipei: Sense Publishers.

Kyomuhendo, B. (Ed.). (2001). Women in academia: Voices from the South. Uganda: Makerere University. Retrieved August 5, 2012, from www.unit.no?semut?rapporte-doks?url-NUFU-Gender?pdf-KAPOTLER?9751Batebya.pdf

Leathwood, C., \& Read, B. (2009). Gender and the changing face of higher education: A feminized future? New York: Open University Press.

Lulat, G. Y. M. (2005). African history of higher education from antiquity to the present: Critical synthesis. Westport, London: Praeger Publisher.

Magubushka, A. M., Schomburg, H., \& Teichler, U. (Eds.). (2007). Higher education and work in Africa: A comparative empirical study in selected countries. Kassel: University of Kassel Press.

Meena, R. (2007). Women's participation in higher levels of learning in Africa. In N. T. Assié-Lumumba (Ed.), Women and higher education in Africa: Reconceptualizing gender-based human capabilities and upgrading human rights to knowledge (pp. 75-108) Abidjan: CEPARRED.

Morrow, W. (2007). Learning to teach in South Africa. Cape Town: HSRC Press.

Peters, M. A., and Roberts, P. (2008). Neoliberalism, Higher Education and Research. Rotterdam/Taipei: Sense Publishers.

Rottenburg, R. (1986, December). New approaches to university staff development: Training for efficiency in teaching, research and management. A report on the International Conference, Berlin. 
Sawyerr, A. (2002). Challenges facing African universities: Selected issues. Retrieved May 16, 2012, from www.aau.org/english/ documents/asa_challengesfigs.pdf.

Spencer, P. (2012). Nationalism, the postcolonial state and genocide. Lecture presented at the University of Hamburg: Germany, held at Von-Melle-Park 6, Hörsaal F, April 19, 2012.

Subotzky, G. (1999). Beyond the entrepreneurial university: The potential role of South Africa's historical disadvantaged institutions in reconstruction and development. International Review of Education, 507-527.

Teferra, D., \& Altbach, P. (2004). African higher education: Challenges for the 21st century. Higher Education, 47(1), 221-250.

UNESCO. (1998, March). Higher education for a new Africa: A student's vision. A Forum of Student Associations in Africa on Higher Education in the 21st Century, Accra, Ghana.

UNESCO-UIS. (2009). Global Education Digest: Comparing education statistics around the world. Montreal: UNESCO Institute for Statistics. Retrieved May 18, 2012, from www.uis.unesco.org/Library/Documents/ged09-en.pdf

Wallbank, W. T. (1964). Contemporary Africa: Continent in transition. Toronto: Van Nostrand.

Waghid, Y. (2012). The decline of the university in South Africa: Reconstituting the place of reason. In: R. Barnett (Ed.), The future university: Ideas and possibilities (pp. 71-83). New York, London: Routledge.

Yizengaw, T. (2008). Challenges of higher education in Africa and lessons of experience for the Africa-U.S. higher education collaboration initiative. Washington DC: The World Bank.

Zeleza, P. T. (2004). Neo-liberalism and academic freedom. In: A. Olukoshi \& P. T. Zeleza (Eds.). African universities in the twenty-first century. Neo-liberalism and internationalization (Volume I, pp. 42-68). Dakar: CODESRIA. 